\title{
PENINGKATAN KESEHATAN PENDERITA DIABETES MELITUS di MASA PANDEMI COVID-19 DENGAN SENAM PROLANIS
}

\author{
Wirda Faswita $^{1 *}$, Leny Suarni ${ }^{2}$, Sri Wahyuni $^{3}$, Leli Herawati ${ }^{4}$ \\ STIKes Sehat Medan, Medan, Indonesia \\ email: wirdafaswita@gmail.com, lenysuarni2016@gmail.com,wahyuni0130@gmail.com, \\ leliherawati0987@gmail.com
}

\begin{abstract}
ABSTRAK
Coronavirus Disease 2019 (COVID-19) merupakan penyakit menular yang disebabkan oleh Severe Acute Respiratory Syndrome Coronavirus 2 (SARS-CoV-2) yang merupakan coronavirus jenis baru yang belum pernah diidentifikasi sebelumnya pada manusia. Penyakit Diabetes Mellitus (DM) merukan salah satu faktor komorbiditas dalam kejadian COVID-19 dimana jumlah penderita diabetes melitus yang semakin meningkat setiap tahunnya. salah satu program yang ada dalam PROLANIS yaitu Latihan fisik yang juga merupakan salah satu pilar dalam mengontrol kadar gula darah pada pendeirta diabetes mellitus yang merupakan. Kegiatan aktivitas fisik yang untuk penderita DM dalam pengontrolan Kadar Glukosa Darah (KGD) yaitu olahraga tingkat sedang seperti aerobik, latihan berjalan cepat, latihan sepeda, latihan lari, dan renang. Senam prolanis dilaksanakan pada kegiatan posyandu lansia sebanyak seminggu sekali dengan jumlah latihan selama 60 menit dengan dipandu oleh instruktur senam
\end{abstract}

Kata Kunci: Peningkatan Kesehatan; Diabetes Mellitus; Pandemi Covid-19, Senam Prolanis

\section{PENDAHULUAN}

Penambahan jumlah kasus COVID-19 berlangsung cukup cepat dan sudah terjadi penyebaran ke luar wilayah Wuhan dan negara lain. Sampai dengan 16 Februari 2020, secara global dilaporkan 51.857 kasus konfimasi di 25 negara dengan 1.669 kematian (CFR 3,2\%) (Kementerian Kesehatan RI, 2020). Terdapat dua jenis virus penyebab COVID-19 yang diketahui menimbulkan komplikasi, seperti Middle East Respiratory Syndrome (MERS) dan Severe Acute Respiratory Syndrome (SARS). Manifestasi klinis yang secara umum bisa menimbulkan infeksi COVID-19 antara lain gejala gagal napas akut seperti hipertermia, batuk, dan gejala sesak. Masa inkubasi rata-rata 5-6 hari, masa inkubasi maksimal 14 hari. Dalam kasus yang parah, COVID-19 juga dapat menyebabkan penyakit pneumonia, infeksi saluran nafas akut, kerusakan ginjal, dan bahkan menyebabkan kematian (Kementerian Kesehatan RI, 2020). 
Salah satu penyebab terjadinya kejadian penyakit COVID-19 adalah penyakit komorbid dimana adanya hubungan yang terjadi antara kejadian COVID-19 dengan umur, jenis kelamin, infeksi nosokomial dari penderita dan rumah sakit, penyakit komorbid seperti hipertensi, diabetes mellitus, penyakit kardiovaskuler dan PPOK dengan nilai $p$-value yang didapat $p<0,05$ (Hidayani, 2020). Selain itu menurut Roeroe et al., (2021) Diabetes Melitus (DM) menjadi salah satu penyakit kronis yang bersifat katastro-fik karena memiliki angka morbiditas dan mortalitas yang tinggi di dunia, baik di negara-negara maju, maupun di negara berkembang sehingga menjadi hal penting untuk diperhatikan terutama saat adanya pandemi COVID-19, suatu penyakit infeksi virus yang terutama menyerang saluran pernapasan. COVID-19 dengan gejala klinis sebagian besar mengalami batuk dan demam sedangkan penyakit penyerta terbanyak adalah pada pasien hipertensi $(49,8 \%)$ kedua diabetes militus $(35,1 \%)$ (Hikmawati \& Setiyabudi, 2020).

Jumlah penderita DM telah meningkat sejak tahun 1980 sampai 2014 di dunia dengan jumlah peningkatan dari 108 juta menjadi empat kali lebih tinggi. (World Health Organization, 2016). Sejak tahun 2013, prevalensi DM di Indonesia pada penduduk dengan umur $\geq 15$ tahun meningkat menjadi 2\%(Kementerian Kesehatan Republik Indonesia, 2018). Provinsi Sumatera Utara tahun 2013, menunjukkan kasus DM pada umur $\geq 15$ tahun yaitu sebesar 1,8 persen. Kasus tertinggi terdiagnosis DM pada umur $\geq 15$ tahun terdapat pada Kabupaten Deli Serdang yaitu sebesar 2,9 persen dilajutkan dengan Kota Medan yaitu sebesar 2,7 persen, Kota Pematang Siantar yaitu sebesar 2,2 persen, Kabupaten Asahan yaitu sebesar 2,1 persen dan Kota Gunung Sitoli yaitu sebesar 2,1 persen. Angka kejadian terendah yaitu di Kabupaten Mandailing Natal sebesar 0,3 persen. Angka kejadian DM tertinggi berdasarkan jenis kelamin untuk perempuan sebesar 1,9 persen dan laki-laki yaitu sebesar 1,6 persen (Pusdatin, 2018).

PROLANIS merupakan program pelayanan kesehatan dan pendekatan proaktif yang dilaksanakan secara terintegrasi dengan mengikuti keterlibatan peserta dan menggunaan fasilitas kesehatan dan BPJS Kesehatan demi tercapainya pemeliharaan kesehatan untuk anggota BPJS Kesehatan yang menderita penyakit kronis yang bertujuan meningkatkan kualitas hidup yang optimal dengan pembiayaan dalam pelayanan kesehatan yang efektif dan efisien. Kegiatan PROLANIS meliputi kegiatan konsultasi masalah kesehatan dan pemberian edukasi kesehatan, kunjungan rumah, pengingat, aktifitas kelompok dan penilaian status kesehatan secara rutin (BPJS, 2014).

Salah satu program PROLANIS yang dilakukan yaitu latihan fisik pada penderita penyakit kronis. Pengabdi memilih kegiatan aktivitas fisik dalam hal ini berbentuk latihan senam seperti senam kebugaran jasmani, senam diabetik dan senam lanjut usia. Latihan fisik adalah salah satu aktivitas dalam pengelolaan DM yang menjadi Pilar penatalaksanan DM yaitu edukasi kesehatan, nutrisi, latihan kebugaran jasmani, dan terapi obat. Program latihan fisik pada penderita DM sebaiknya dilakukan secara teratur dimana yang menjadi catatan penting adalah aktivitas kehidupan sehari-hari bukan termasuk latihan fisik. (Perkeni, 2019).

Hasil penelitian yang dilakukan oleh (Hasfika et al., 2020) didapatkan bahwa rata-rata penurunan KGD adalah 5,918 mq/dl dengan SD 11,549. Hasil penelitian menunjukkan adanya pengaruh senam prolanis terhadapa penurunan KGD dengan hasil p-value 0,001 yaitu < 0,05. Hal ini sejalan dengan penelitian yang dilakukan oleh Nurayati \& Adriani (2017) dimana penderita DM tipe 2 di wilayah kerja Puskesmas Mulyorejo kota Surabaya sebagian besar 
mempunyai aktivitas fisik rendah dengan KGD puasa kategori diatas normal sebanyak 30 orang $(76,9 \%)$. Hasil uji statistik Spearman's rho menunjukkan nilai $\mathrm{p}=0,000$ yaitu nilai $\mathrm{p}$ kecil dari alpha yang berarti terdapat hubungan aktivitas fisik dengan kadar gula darah puasa responden penderita Diabetes Melitus tipe 2.

Desa Sei Limbat merupakan Desa binaan STIKes Sehat Medan yang berada di Kabupaten Langkat Kecamatan Selesai. Luas Wilayah 10,35 $\mathrm{km}^{2}$. Jumlah lanjut usia yang memiliki penyakit seperti diabetes mellitus, rematik dan hipertensi termasuk tinggi yaitu sekitar $45 \%$. Berdasarkan hal tersebut maka dilakukan kegiatan pengabdian masyarakat program senam diabetes yang merupakan salah satu bagian dari senam prolanis dalam peningkatan kesehatan penderita Diabetes Melitus di masa pandemi COVID-19.

\section{Metode}

Jumlah penderita DM di Desa Sei Limbat Kecamatan Selesai Kabupaten Langkat tahun 2021 yang terdata sebesar 125 orang. Hal ini dikarenakan masih banyaknya penderita DM yang enggan melakukan kontrol kadar gula darah sehingga perlu adanya program Senam Prolanis yang dilaksanakan secara rutin dalam peningkatan kesehatan penderita Diabetes Melitus. Melihat pentingnya latihan senam Prolanis yang merupakan salah satu pilar penatalaksanaan DM maka perlu adanya kegiatan program senam prolanis yang dilaksanakan selama lebih kurang 60 menit setiap 2 kali seminggu. Tujuan kegiatan senam ini adalah untuk mengontrol KGD pada penderita DM Desa Sei Limbat Kecamatan Selesai Kabupaten Langkat.

\section{Hasil dan Pembahasan}

Kegiatan senam prolanis yang dilaksanakan di Balai Desa di Desa Sei Limbat Kecamatan Selesai Kabupaten Langkat bertujuan untuk peningkatan kesehatan penderita DM. Peserta yang mengikuti sebanyak 20 orang dengan lanjut usia di Desa Sei Limbat.

Pelaksanaan latihan senam prolanis dimulai dengan melakukan pemeriksaan kesehatan seperti tekanan darah dan KGD. Penderita DM dengan KGD kurang dari $100 \mathrm{mg} / \mathrm{dL}$ atau Tekanan Darah diatas 90/60 dan wajib mengkonsumsi karbohidrat sebelum melakukan latihan dahulu dan bila nilai KGD diatas $250 \mathrm{mg} / \mathrm{dL}$ atau Tekanan Darah diatas 130/85, pengabdi tidak mengizinkan peserta mengikuti latihan senam. Selanjutnya peserta yang memenuhi syarat pelaksanaan latihan senam prolanis melakukan kegiatan senam dengan instruktur yang terdiri atas latihan pemanasan 30 menit, diikuti latihan inti 20 menit dan diakhiri dengan latihan pendinginan 10 menit stiap akhir sesi diberikan jeda 10 menit untuk istirahat bagi para peserta.

Hasil penelitian Patima et al., (2019) berjudul "Pengaruh Senam Prolanis Terhadap Penurunan Kadar Gula Darah Penderita Diabetes Melitus Tipe 2 Pada Lansia Di Puskesmas Binuang, Polman" menunjukkan terdapat perbedaan bermakna antara KGD puasa pada responden sebelum dan setelah mengikuti senam aerobik dengan nilai $p$ kecil dari 0,05 . Ratarata KGD puasa sebelum latihan senam adalah $81,66 \pm 13,14 \mathrm{mg} / \mathrm{dL}$, sedangkan rata - rata 
kadar glukosa darah puasa setelah senam adalah 67,81 $\pm 4,49 \mathrm{mg} / \mathrm{dL}$. Artinya Senam Prolanis dapat menyebabkan penurunan kadar glukosa darah .

Menurut (R Puspitha et al., 2020)sejak tahun 2014, BPJS telah melakukan penerapan Program Pengolahan Penyakit Kronis (PROLANIS) seperti latihan senam prolanis adalah salah satu program dalam sistem pelayanan kesehatan. Paramitha (2014) menjelaskan kegiatan latihan fisik jika dilakukan secara teratur akan dapat menurunkan KGD dan sebaliknya jika latihan fisik kurang atau tidak dilakukan secara teratur maka akan dapat meningkatkan KGD pada pasien Diabetes Mellitus. Aktivitas fisik seperti senam prolanis pada lanjut usia jika dilakukan dengan rutin dapat meningkatkan kebugaran fisik seperti latihan senam prolanis yang dapat meningkatkan fungsi jantung dan menurunkan tekanan darah serta mengurangi resiko penumpukan lemak pada dinding pembuluh darah, menjaga elastisitas pembuluh darah dan melatih otot jantung berkontraksi.
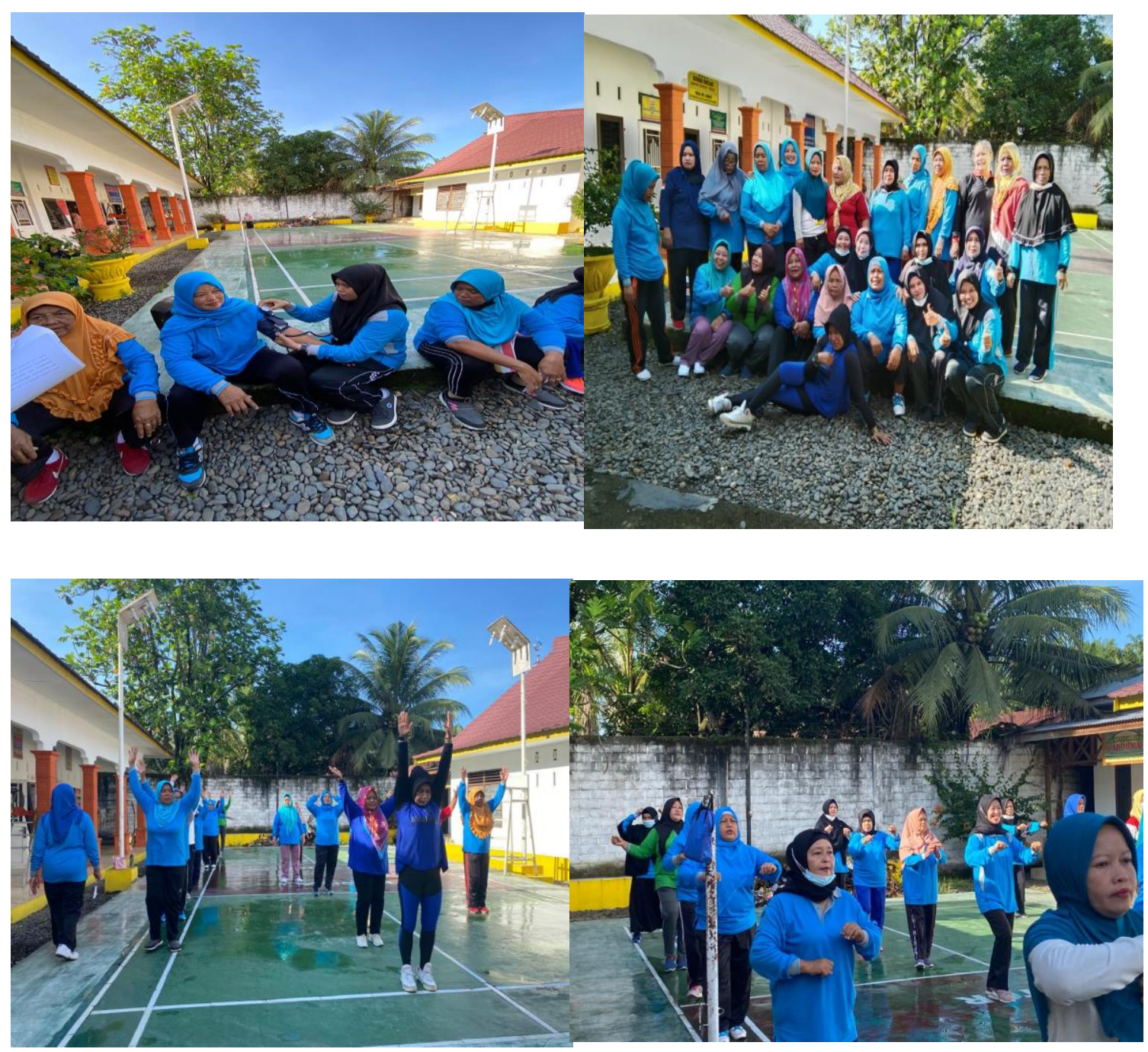


\section{Kesimpulan}

Kegiatan pengabdian kepada masyarkat di Desa Sei Limbat Kecamatan Selesai Kabupaten Langkat berjalan dengan lancar, seluruh peserta bisa melaksanakan seluruh kegiatan tanpa mengalami masalah kesehatan. Dari hasil yang didapatkan terjadi penurunan Kadar Gula Darah rata-rata pada 18 orang peserta program senam Prolanis menjadi <200 $\mathrm{mg} / \mathrm{dL}$ dan rata-rata penurunan $50 \mathrm{mg} / \mathrm{dL}$ dan Tekanan Darah rata-rata 120/70 $\mathrm{mmHg}$ sebanyak 15 peserta. Diharapkan untuk kegiatan pengabdian masyarakat selanjutnya melakukan kegiatan 4 pilar penatalaksanaan dalam mengontrol Kadar Gula Darah yaitu edukasi, terapi nutrisi, aktifitas fisik dan farmakologi.

\section{Ucapan Terima Kasih}

Puji dan syukur saya ucapkan kepada Allah SWT atas segala rahmat, karunia, dan hidayah-Nya sehingga penulis bisa menyelesakan kegiatan Pengabdian kepada Masyarakat dengan judul "Peningkatan Kesehatan Penderita Diabetes Melitus di Masa Pandemi Covid-19 dengan program Prolanis". Tidak lupa pula sholawat berangkaikan salam dihadiahkan kepada Nabi Muhammad SAW berserta keluarga dan para sahabat.

Penulis mengucapkan terimakasih pada keluarga yang memberi dukungan sehingga kegiatan pengabdian kepada masyarakat ini bisa berjalan dengan baik.

Secara khusus penulis juga ingin mengucapkan terimakasih yang sebesar-besarnya kepada Bapak Ketua STIKes Sehat Medan Ilham Syahputra Siregar, S.Kep., M.Kes. yang telah memberikan dukungan dalam melaksanakan pengabdian kepada masyarakat. Serta kepada Bapak Kepala Desa Sei Limbat Kecamatan Selesai Kabupaten Langkat yang sudah memberikan izin dan juga menyedian tempat pelaksanaan kegiatan pengabdian masyarakat menajdi lancar, serta kepada masyarakat Desa Sei Limbat yang bersedia bekerjasama dalam kegiatan ini yang telah bersedia menjadi peserta dalam pelaksanaan pengabdian kepada masyarakat.

\section{Referensi}

BPJS. (2014). Panduan praktis Prolanis (Program pengelolaan penyakit kronis). BPJS Kesehatan.

Hasfika, I., Erawati, S., \& Sitorus, F. E. (2020). Pengaruh Senam Prolanis Terhadap Pengendalian Kadar Glukosa Darah dan Tekanan Darah Pada Pasien Diabetes Melitus Tipe II dan Hipertensi. BEST Journal (Biology Education, Sains and Technology), 3(2), 184-190. https://doi.org/10.30743/best.v3i2.3226

Hidayani, W. R. (2020). Faktor Faktor Risiko Yang Berhubungan Dengan COVID 19: Literature Review. Jurnal Untuk Masyarakat Sehat (JUKMAS), 4(2), 120-134. https://doi.org/10.52643/jukmas.v4i2.1015

Hikmawati, I., \& Setiyabudi, R. (2020). Hipertensi Dan Diabetes Militus Sebagai Penyakit Penyerta Utama Covid-19 Di Indonesia Hypertension and Diabetes Mellitus As Covid19 Comorbidities in Indonesia. Prosiding Seminar Nasional Lppm Ump, O(0), 95-100. 
Kementerian Kesehatan Republik Indonesia. (2018). Infodatin-Diabetes.Pdf. Pusat Data Dan Informasi Kementerian Kesehatan.

Kementerian Kesehatan RI. (2020). Pedoman Pencegahan dan Pengendalian Coronavirus Disease (Covid-19) Juli 2020. Germas, 18(2), 20.

Nurayati, L., \& Adriani, M. (2017). Hubungan Aktifitas Fisik dengan Kadar Gula Darah Puasa Penderita Diabetes Melitus Tipe 2. Amerta Nutrition, 1(2), 80. https://doi.org/10.20473/amnt.v1i2.6229

Paramitha, G. M. (2014). Hubungan Aktivitas Fisik dengan Kadar Gula Darah Pada Pasien Diabetes Mellitus Tipe 2 di Rumah Sakit Umum Daerah Karanganyar. Fakultas Kedokteran, Universitas Muhammadiya Surakarta, c, 1-43.

Patima, N., Darwis, D., \& Hasanuddin, H. (2019). Pengaruh Senam Prolanis Terhadap Penurunan Kadar Gula Darah Penderita Diabetes Melitus Tipe 2 Pada Lansia Di Puskesmas Binuang, Polman. Jurnal Ilmiah Kesehatan Diagnosis, 14(4), 343-346. https://doi.org/10.35892/jikd.v14i4.287

Perkeni, 2019. (2019). Pedoman pengelolaan dan pencegahan diabetes melitus tipe 2 dewasa di Indonesia 2019. Perkumpulan Endokrinologi Indonesia, 1-117.

Pusdatin. (2018). Hari Diabetes Sedunia Tahun 2018. . Retrieved Februari 18, 2020, from Pusdatin Kemenkes: Https://Pusdatin.Kemkes.Go.Id/Article/View/19041500002/HariDiabetes-Sedunia-2018.Html.

R Puspitha, A., Erika, K. A., \& Saleh, U. (2020). Pemberdayaan Keluarga dalam Perawatan Tuberkulosis ( TB ). Media Karya Kesehatan, 3(1), 50-58.

Roeroe, P. A. L., Sedli, B. P., \& Umboh, O. (2021). Faktor Risiko Terjadinya Coronavirus Disease 2019 (Covid-19) pada Penyandang Diabetes Melitus Tipe 2. E-CliniC, 9(1), 154160. https://doi.org/10.35790/ecl.v9i1.32301

World Health Organization. (2016). Global Report on Diabetes. Isbn, 978, 6-86. 